\title{
Aerobic Sludge Granulation in a Full-Scale Sequencing Batch Reactor
}

\author{
Jun Li, ${ }^{1}$ Li-Bin Ding, ${ }^{1}$ Ang Cai, ${ }^{1}$ Guo-Xian Huang, ${ }^{2}$ and Harald Horn ${ }^{3}$ \\ ${ }^{1}$ Department of Municipal Engineering, Zhejiang University of Technology, No. 18 Chao Wang Road, Hangzhou 310014, China \\ ${ }^{2}$ Yancang Wastewater Treatment Plant, Haining 314422, China \\ ${ }^{3}$ Water Chemistry and Water Technology, Karlsruhe Institute of Technology, Engler-Bunte-Ring 1, 76173 Karlsruhe, Germany
}

Correspondence should be addressed to Jun Li; tanweilijun@zjut.edu.cn

Received 25 February 2014; Accepted 23 March 2014; Published 15 April 2014

Academic Editor: Hongjuan Liu

Copyright (C) 2014 Jun Li et al. This is an open access article distributed under the Creative Commons Attribution License, which permits unrestricted use, distribution, and reproduction in any medium, provided the original work is properly cited.

\begin{abstract}
Aerobic granulation of activated sludge was successfully achieved in a full-scale sequencing batch reactor (SBR) with $50,000 \mathrm{~m}^{3} \mathrm{~d}^{-1}$ for treating a town's wastewater. After operation for 337 days, in this full-scale SBR, aerobic granules with an average SVI ${ }_{30}$ of $47.1 \mathrm{~mL} \mathrm{~g}^{-1}$, diameter of $0.5 \mathrm{~mm}$, and settling velocity of $42 \mathrm{~m} \mathrm{~h}^{-1}$ were obtained. Compared to an anaerobic/oxic plug flow $(\mathrm{A} / \mathrm{O})$ reactor and an oxidation ditch $(\mathrm{OD})$ being operated in this wastewater treatment plant, the sludge from full-scale SBR has more compact structure and excellent settling ability. Denaturing gradient gel electrophoresis (DGGE) analysis indicated that Flavobacterium sp., uncultured beta proteobacterium, uncultured Aquabacterium sp., and uncultured Leptothrix sp. were just dominant in SBR, whereas uncultured bacteroidetes were only found in A/O and OD. Three kinds of sludge had a high content of protein in extracellular polymeric substances (EPS). X-ray fluorescence (XRF) analysis revealed that metal ions and some inorganics from raw wastewater precipitated in sludge acted as core to enhance granulation. Raw wastewater characteristics had a positive effect on the granule formation, but the SBR mode operating with periodic feast-famine, shorter settling time, and no return sludge pump played a crucial role in aerobic sludge granulation.
\end{abstract}

\section{Introduction}

Aerobic granulation is a novel and promising technology for wastewater treatment [1-3]. Aerobic granular sludge is formed by microbial self-aggregation and has advantages such as excellent settling ability, dense and strong microbial structure, high biomass retention, ability to withstand a high organic loading rate and tolerance to toxicity compared with conventional activated sludge [4-7]. However, the operational conditions of aerobic granular sludge are strictly limited by factors like reactor configuration, substrate composition, selecting pressure, volume exchange ratio, hydrodynamic shear force, organic loading rate (OLR), feastfamine regime, feeding strategy and cycle time $[8,9]$. To date, it still lacks in theoretical models to explain the mechanism of aerobic granulation although several hypotheses and mathematic models have been proposed [10]. Furthermore, most of the previous studies on aerobic granulation were carried out in laboratory-scale reactors $[5,9]$ and only a few were done in pilot-scale reactors [11-14]. In addition, there is very limited literature available although several full-scale plants have been built in the Netherlands, Portugal and South Africa $[15,16]$.

The world's first pilot-scale aerobic granular sludge reactor for real wastewater treatment was started up in September 2003 in Ede, the Netherlands, consisting of two parallel biological reactors with a height and diameter of $6 \mathrm{~m}$ and $0.6 \mathrm{~m}$, respectively [11]. An SBR with a working volume of $1 \mathrm{~m}^{3}$ and a diameter of $0.5 \mathrm{~m}$ for treating low-strength wastewater in a wastewater treatment plant (WWTP) in China [12] and another SBR with a working volume of $0.1 \mathrm{~m}^{3}$ and a diameter of $0.25 \mathrm{~m}$ fed with synthetic wastewater in Spain [14] were built up. Aerobic granules were successfully cultivated in all these previous pilot-scale systems. The results showed that reasonable organic loading rate, high H/D ratio, sequencing batch operation and settling time still could be 
necessary factors. A recent study showed that an intensive anaerobic contact of granules and easily degradable organic carbon at the beginning of each SBR cycle stabilize granular growth, phosphorus and nitrogen removal [17].

Gansbaai WWTP was reported to be the first full-scale domestic sewage treatment work in the world using aerobic granular sludge technology in an upgrade project $[15,18]$. It was designed for $4,000 \mathrm{~m}^{3} \mathrm{~d}^{-1}$ of high strength septic influent consisting of three parallel reactors with a height of $7 \mathrm{~m}$ and diameter of $18 \mathrm{~m}$. Another full-scale SBR in Epe, the Netherlands, was designed for 59,000 person equivalents and treating up to $1,500 \mathrm{~m}^{3} \mathrm{~h}^{-1}$ municipal wastewater with a high contribution of industrial waste from slaughterhouses [15]. Nevertheless, the detailed data of the operational performance of full-scale applications have not been presented.

Yancang WWTP was located in Haining, a coastal city in Eastern China. Attention has been paid because some small particles were observed in activated sludge from both anaerobic/oxic plug flow process $(\mathrm{A} / \mathrm{O})$ and oxidation ditch process (OD) in this plant since 2008. Particularly, about 60$79 \mathrm{~mL} \mathrm{~g}^{-1}$ of SVI indicated that the sludge from these two continuous flow reactors had better settling ability compared with normal activated sludge.

The major aim of this work was to demonstrate the feasibility of cultivating aerobic granular sludge in an SBR, particularly for full-scale application. Successively, a lab-scale SBR, a pilot-scale SBR and a full-scale SBR were set up and used for the treatment of this wastewater through the development of aerobic granular sludge. The characteristics of different sludges from A/O, OD and SBR were compared. The main factors for aerobic sludge granulation in this fullscale SBR were discussed.

\section{Material and Methods}

2.1. Wastewater and Inoculating Sludge. Wastewater in Yancang WWTP included approximately 30\% domestic sewage and $70 \%$ industrial wastewater from printing and dyeing, chemical, textile and beverage. The characteristics of the wastewater were showed as follows: chemical oxygen demand $\left(\mathrm{COD}_{\mathrm{Cr}}\right)$ of $200-600 \mathrm{mg} \mathrm{L}^{-1}$, biochemical oxygen demand (BOD) of 50-105 $\mathrm{mg} \mathrm{L}^{-1}$, ammonium nitrogen $\left(\mathrm{NH}_{4}{ }^{+}-\mathrm{N}\right)$ of 28.0-40.0 $\mathrm{mg} \mathrm{L}^{-1}$, total phosphorus (TP) of $2.0-4.0 \mathrm{mg} \mathrm{L}^{-1}$ and temperature of $18-30^{\circ} \mathrm{C}$. The average influent BOD/COD ratio was only about 0.23 which belonged to bio-refractory wastewater. The lab-scale, pilot-scale and full-scale SBR were all introduced with the same raw wastewater and inoculated sludge from the second sedimentation tank in OD.

2.2. The A/O Set up and Operation. The A/O process was built and came into operation in 2001 treating $10,000 \mathrm{~m}^{3}$ per day (Figure 1(a)). It included a regulation tank, reaction tank, primary sedimentation tank, A/O tank, second sedimentation tank, oxidation contact tank and final sedimentation tank. The A/O plug flow process in this WWTP was designed and operated in a traditional way. The second sedimentation tank was separately built with the main bioreactor and the returned sludge was pumped from second sedimentation tank to anaerobic zone. It include an bioreactor consisted of an anaerobic zone with a size of $25 \mathrm{~m}$ length, $25 \mathrm{~m}$ width and $5 \mathrm{~m}$ depth followed by an oxic zone with a size of $55 \mathrm{~m}$ length, $25 \mathrm{~m}$ width and $5 \mathrm{~m}$ depth.

2.3. The OD Set up and Operation. In order to meet the treating requirements of the increasing wastewater, the second stage project of the OD process with a treating capacity of $50,000 \mathrm{~m}^{3} \mathrm{~d}^{-1}$ came into operation in 2006 (Figure $1(\mathrm{~b})$ ). It included a regulation tank, primary sedimentation tank, hydrolysis acidification tank, aerobic tank, second sedimentation tank and final sedimentation tank. The aerobic tank had a size of $90 \mathrm{~m}$ length, $35 \mathrm{~m}$ width and $3.5 \mathrm{~m}$ depth. The OD was designed and operated in a traditional way. The second sedimentation tank was separately built with the main bioreactor of OD. The returned sludge from second sedimentation tank was pumped to the main bioreactor of OD.

2.4. Lab-Scale SBR Set up and Operation. A column type lab-scale SBR with an H/D ratio of 2.5, working volume of $5.0 \mathrm{~L}$ and volumetric exchange ratio of $50 \%$ was set up in 2008 (Figure 2(a)). It was reported that Kong had successfully developed aerobic granules in four SBRs with different H/D ratio of $24,16,8$ and 4 , respectively and a higher reactor $\mathrm{H} / \mathrm{D}$ ratio such as $20-30$ was mostly used in literature to meet the requirement of the minimal settling velocity for granule formation [19]. So here, we defined that the reactor with an H/D below 4 was considered to be low. The raw wastewater was introduced from top of the reactor with a volume of $2.5 \mathrm{~L}$ per cycle. The lab-scale reactor was aerated by using a fine bubble aerator and operated in a fill-draw mode. After inoculation, the SBR was initially operated in successive cycles of $4 \mathrm{~h}$, and each cycle consisted of $1 \mathrm{~min}$ of filling, $120 \mathrm{~min}$ of aeration, $60 \mathrm{~min}$ of settling, $20 \mathrm{~min}$ of effluent withdraw and 39 min of idling. After 10 days, the SBR was operated in a cycle of $4 \mathrm{~h}$, which consisted of 1 minute of filling, $180 \mathrm{~min}$ of aeration, $10 \mathrm{~min}$ of settling, $20 \mathrm{~min}$ of effluent withdraw and 29 min of idling (Table 1). The organic loading rate (OLR) of the influent was controlled at $3.9-4.5 \mathrm{~kg}$ COD $\mathrm{m}^{-3} \mathrm{~d}^{-1}$ and superficial air velocity was controlled at $1.3 \mathrm{~cm} \mathrm{~s}^{-1}$. A programmable logic controller (PLC) controlled the implementation of the pumps, valves and the length of every operational batch cycle.

2.5. Pilot-Scale SBR System Set up and Operation. A grit chamber, a service tank and two parallel columns constituting the pilot-scale SBR system was set up in 2009 (Figure 2(b)). The two parallel columns had a height of $6 \mathrm{~m}$, an internal diameter of $2 \mathrm{~m}, \mathrm{H} / \mathrm{D}$ of 2.5 and a maximum operating flow rate of $120 \mathrm{~m}^{3} \mathrm{~d}^{-1}$. Fine bubble aerators were used in this pilot-scale SBR. The operation was controlled by a PLC. The pilot-scale SBR system would operate in this way: the raw wastewater was pumped into the grit chamber firstly, and then it flowed into a service tank controlled by electric butterfly valve and level controller. When came to the feeding period, wastewater was pumped into two parallel columns. 

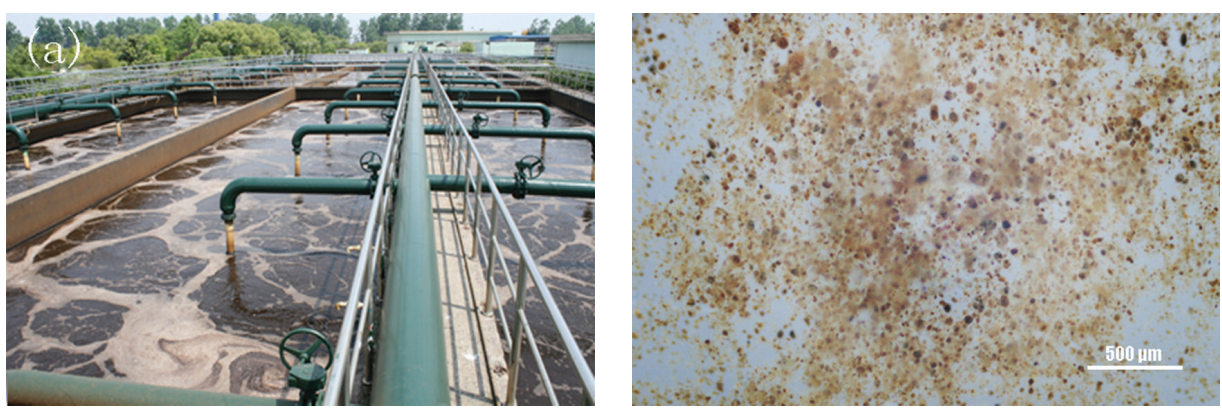

(a) $\mathrm{A} / \mathrm{O}$ and activated sludge, operation since 2001
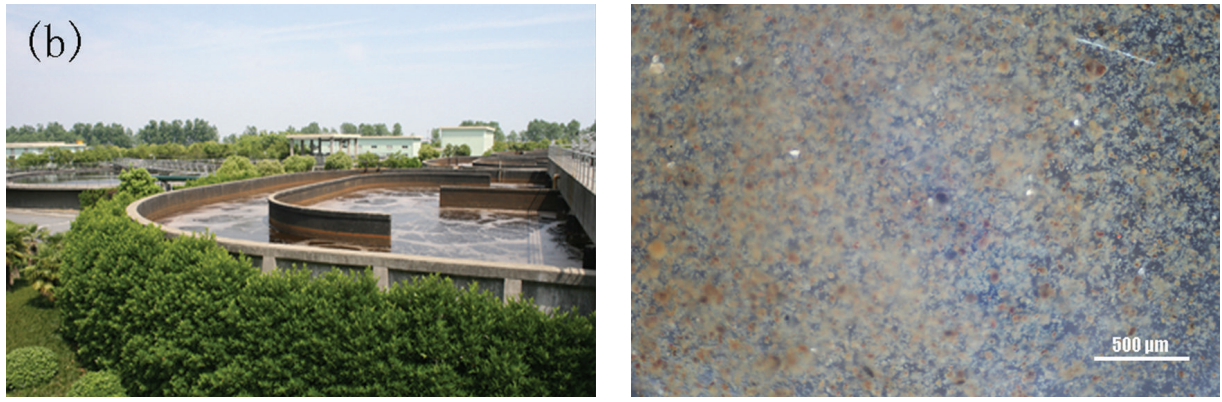

(b) OD and activated sludge, operation since 2007
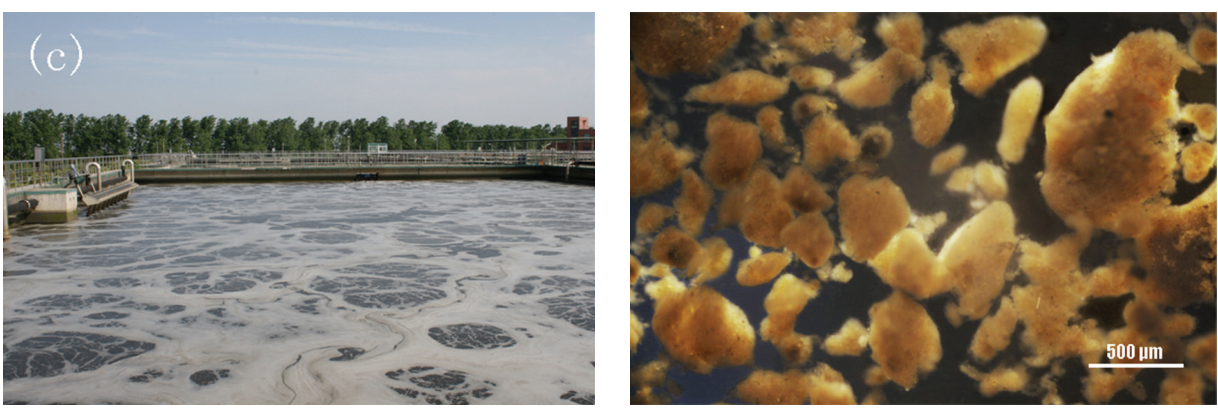

(c) Full-scale SBR and aerobic granules, operation since 2010

FIGURE 1: Photographs of reactors and sludge of A/O, OD and full-scale SBR in Yancang WWTP.

TABLE 1: A cycle distribution of operation time in lab-scale, pilot-scale, and full-scale SBRs.

\begin{tabular}{|c|c|c|c|c|c|c|c|}
\hline \multirow[b]{2}{*}{ Operational cycle } & \multicolumn{2}{|c|}{ Lab-scale SBR } & \multicolumn{2}{|c|}{ Pilot-scale SBR } & \multicolumn{3}{|c|}{ Full-scale SBR } \\
\hline & $0-10 \mathrm{~d}$ & $11-43 d$ & $0-7 \mathrm{~d}$ & $7-50 \mathrm{~d}$ & $0-25 \mathrm{~d}$ & $25-180 \mathrm{~d}$ & 180-now \\
\hline Filling (min) & 1 & 1 & 40 & 40 & 40 & 40 & 40 \\
\hline Aerating (min) & 120 & 180 & 120 & 120 & 240 & 240 & 240 \\
\hline Settling (min) & 60 & 10 & 60 & 20 & 60 & 40 & 50 \\
\hline Discharging (min) & 20 & 20 & 20 & 20 & 30 & 30 & 30 \\
\hline Idling (min) & 39 & 29 & 0 & 40 & 0 & 0 & 0 \\
\hline
\end{tabular}

The wastewater was introduced from the bottom of the pilotscale reactor. The reactor with a volumetric exchange ratio of $50 \%$ was operated in a fill-draw mode. The first stage consisted of $40 \mathrm{~min}$ of influent addition, $120 \mathrm{~min}$ of aeration, 60 min of settling and 20 min of effluent withdraw. After 7 days of operation, it came to the second stage which consisted of $40 \mathrm{~min}$ of influent addition, $120 \mathrm{~min}$ of aeration, $20 \mathrm{~min}$ of settling and 20 min of effluent withdraw (Table 1).
2.6. The Full-Scale SBR and Operation. With the expansion of service area and urbanization, an A/O with a treating capacity of $10,000 \mathrm{~m}^{3} \mathrm{~d}^{-1}$ constructed in 1999 and an OD with a treating capacity of $50,000 \mathrm{~m}^{3} \mathrm{~d}^{-1}$ constructed in $2006 \mathrm{did}$ not match with the increasing wastewater. A new wastewater treatment work with a treating capacity of $50,000 \mathrm{~m}^{3} \mathrm{~d}^{-1}$ was required in this plant. The aims of building the third stage project in Yancang WWTP were not only to improve 

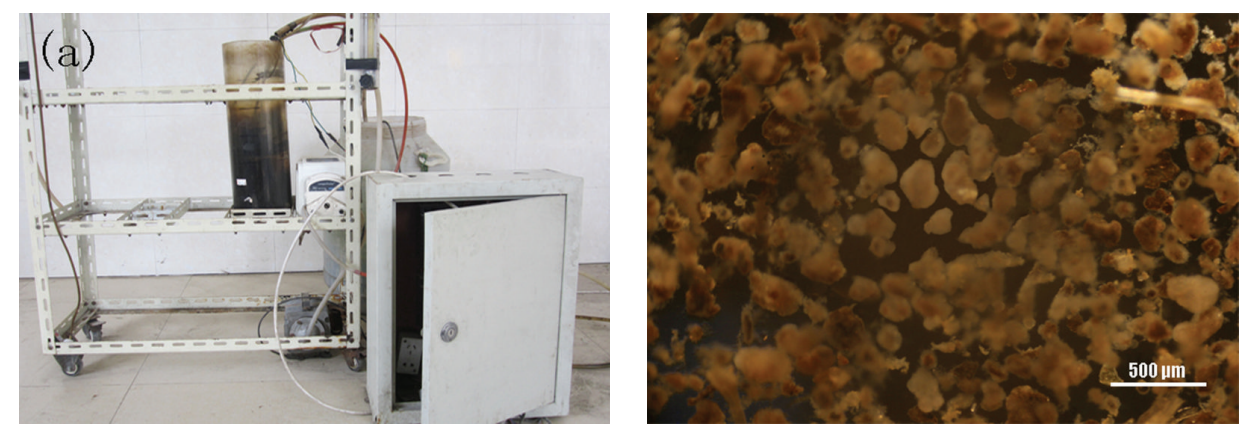

(a) Lab-scale SBR and aerobic granules, operation since 2008
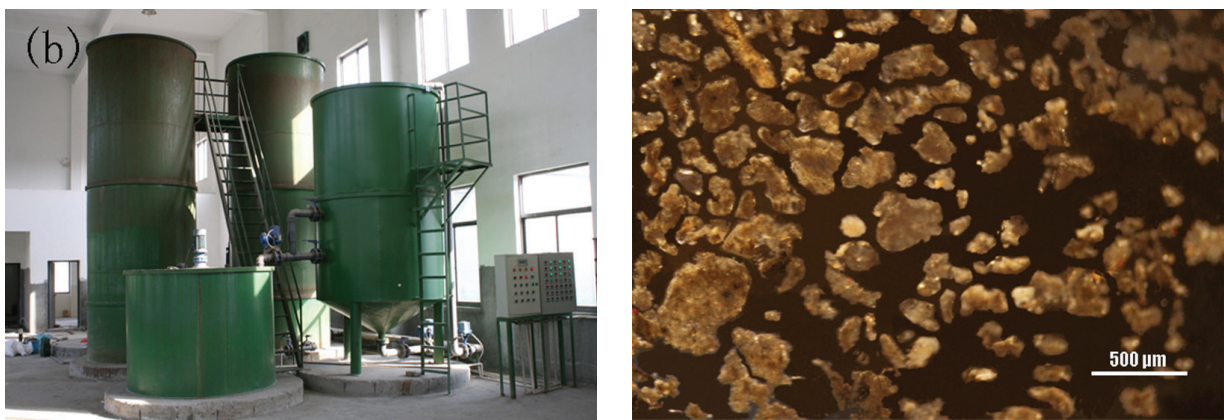

(b) Pilot-scale SBR and aerobic granules, operation since 2009

FIgURE 2: Photographs of reactors and sludge of lab-scale SBR and pilot-scale SBR in Yancang WWTP.

the treatment ability but also to meet the strict wastewater discharging standard in China. Consequently, selecting a more effective and economic process for treating wastewater was an urgent issue. Activated sludge with an SVI of 60$79 \mathrm{~mL} \mathrm{~g}^{-1}$ and some small granules with the size of $30-$ $80 \mu \mathrm{m}$ existing in the $\mathrm{A} / \mathrm{O}$ and $\mathrm{OD}$ process enlightened us whether it was feasible to cultivate aerobic granular sludge with SBR process for treating wastewater in Yancang WWTP. The A/O plug flow and OD were typical activated sludge process. The only difference was in raw wastewater compared with other WWTP. It implied that raw wastewater was the key factor for the formation of these aggregates in typical A/O plug flow and OD process. If operated in an SBR mode with certain selecting pressure, aerobic granules would be easily formed. Hence, a series of lab-scale and pilot-scale experiments were carried out and proved the feasibility of developing aerobic granules in this treatment plant. After lab-scale and pilot-scale experiments for successful aerobic granulation, the third stage project with a SBR process was built and came into operation in 2010 (Figure 1(c)) and the application of aerobic granular sludge was further studied in this work.

The full-scale SBR was divided into four separated tanks for alternative operating. Each tank had an H/D of 0.09 , a volume of $12,540 \mathrm{~m}^{3}$ with length of $55 \mathrm{~m}$, width of $38 \mathrm{~m}$ and depth of $6 \mathrm{~m}$, respectively. Before raw wastewater flowed into full-scale SBR, it would flow into regulating reservoir, primary sedimentation tank and hydrolysis tank in turn. The effluent quality from full-scale SBR was enhanced by coagulating sedimentation. The wastewater was introduced from top of the full-scale reactor. The full-scale SBR with volumetric exchange ratio of $50 \%-70 \%$ was operated in a fill-draw mode. At the end of 2010, the full-scale SBR was constructed and came into operation. After inoculation, each cycle consisted of $40 \mathrm{~min}$ of filling, about $240 \mathrm{~min}$ of aeration, $60 \mathrm{~min}$ of settling and $30 \mathrm{~min}$ of effluent withdraw. After 25 days, the operation cycle consisted of $40 \mathrm{~min}$ of filling, about $240 \mathrm{~min}$ of aeration, $40 \mathrm{~min}$ of settling and $30 \mathrm{~min}$ of effluent withdraw. Six months later, the operation cycle consisted of $40 \mathrm{~min}$ of filling, about $240 \mathrm{~min}$ of aeration, $50 \mathrm{~min}$ of settling and 30 min of effluent withdraw (Table 1). Accurate aeration time was controlled by an intelligent system depending on variation of dissolved oxygen.

2.7. Analytical Methods. $\mathrm{COD}_{\mathrm{Cr}}, \mathrm{NH}_{4}{ }^{+}-\mathrm{N}$, nitrite $\left(\mathrm{NO}_{2}{ }^{-}-\mathrm{N}\right)$, nitrate $\left(\mathrm{NO}_{3}{ }^{-}-\mathrm{N}\right)$, sludge volume index with 30 min settling time $\left(\mathrm{SVI}_{30}\right)$, mixed liquor suspended solids (MLSS) and mixed liquor volatile suspended solids (MLVSS) were analyzed in accordance to the Standard Methods [20]. Biological Oxygen Demand $\left(\mathrm{BOD}_{5}\right)$ was measured using the WTWOxiTop system. The morphology of sludge was observed by an Olympus CX31 microscope and a digital camera (Canon EOS 30D). The size of granules was analyzed by an image analysis system (Image-Pro Plus 6.0, Media Cybernetics). The element distribution of raw wastewater and granules was analyzed by X-ray fluorescence (XRF). The toxic organic substance in raw wastewater was measured by gas chromatography/mass spectrometry (GC/MS) (SHIMADZU GCMSQP2010). The extracellular polymeric substances (EPS) of granules were extracted using the EDTA extraction method 
[21]. The carbohydrate concentration in EPS was determined as glucose equivalent using enthrone-sulfuric acid method [22], whereas the protein concentration was measured as bovine albumin equivalent using the Lowry method [23].

2.8. DNA Extraction, Polymerase Chain Reaction (PCR) Amplification of Bacterial 16s RNA Gene and Denaturing Gradient Gel Electrophoresis (DGGE). The sludge taken from the reactors was washed twice with PBS buffer. After the samples were centrifuged at $12000 \mathrm{rpm}$ for $10 \mathrm{~min}$, the sludge was immersed into $588 \mu \mathrm{L}$ extraction buffer $(0.1 \mathrm{M}$ Tris$\mathrm{HCl}, 0.1 \mathrm{M} \mathrm{Na}_{2}$-EDTA, 0.1 $\mathrm{M}$ sodium phosphate, $1.5 \mathrm{M} \mathrm{NaCl}$ ) and stored in $-20^{\circ} \mathrm{C}$ freezer until DNA extraction. Beadbeating was applied to produce a suspension of bacterial cells from sludge. Total DNA was extracted with lysozyme, proteinase $\mathrm{K}$, and sodium dodecyl sulfate treatment, followed by phenol/chloroform/isoamyl alcohol (25:24:1) extraction and isopropanol precipitation.

20 ng DNA was amplified using PCR primers P2 and P3 with 40 bases of a GC clamp [24]. PCR conditions and thermal programs for DGGE have been previously described [25]. The PCR-amplified fragments were separated by DGGE using a DCode universal mutation detection system (BioRad Laboratories) as described previously [26]. Quantity One 4.6.2 software (Bio-Rad) was used for band pattern analysis, which was performed by setting background subtraction at 10 using the rolling disk method. The intensity of bands was excluded from analysis which were smaller than 0.05 .

Obtained sequences of DGGE bands were submitted to the GenBank database with assigned accession numbers of KF234427-KF234446 and KF273869, and then compared to the database using the Basic Local Alignment Search Tool-nucleotide (BLASTn) algorithm via http:// www.ncbi.nlm.nih.gov/ for sequence identification. Sequence alignments of $16 \mathrm{~S}$ rRNA partial sequences of reference microbes from Genbank were performed by CLC sequence Viewer software (Version 6.8). DGGE profiles were analyzed by BandScan software (Version 5.0). Microbial diversity was calculated by the Shannon diversity index $(H)$ [27]. Community similarities of DGGE profiles were compared using pairwise similarity coefficients $\left(C_{s}\right)$ [28].

\section{Results and Discussion}

3.1. Formation and Characteristics of the Aerobic Granules in Lab-Scale SBR and Pilot-Scale SBR. In the lab-scale SBR, small granules with irregular and loose structure became visible about 20 days after inoculation. After operating for 43 days, aerobic granules with a mean diameter of $0.3 \mathrm{~mm}$ were dominant in the reactor. The MLSS and SVI in reactor were $6200 \mathrm{mg} \mathrm{L}^{-1}$ and $38 \mathrm{~mL} \mathrm{~g}^{-1}$, respectively. The MLVSS/MLSS ratio increased continuously from $51 \%$ of the inoculating sludge to $70 \%$ of the granules. The average COD removal efficiency was kept at $87.5 \%$ while $\mathrm{NH}_{4}{ }^{+}-\mathrm{N}$ and TP were stabled at $97 \%$ and $86 \%$ respectively. The result indicated that a low $\mathrm{H} / \mathrm{D}$ ratio of the reactor was not the necessary condition for aerobic sludge granulation.

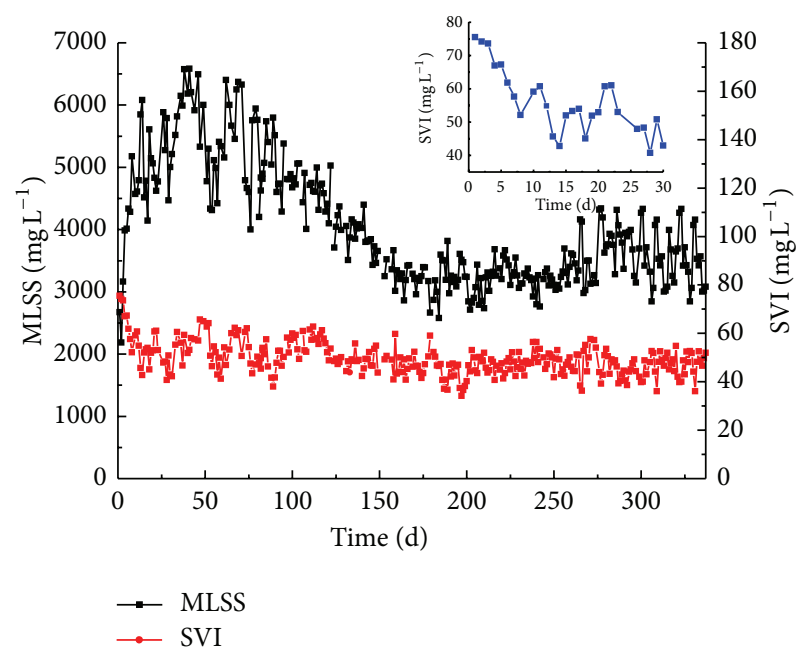

FIgURE 3: The MLSS and $\mathrm{SVI}_{30}$ of the sludge in full-scale SBR in Yancang WWTP from October, 2010 of the seeding sludge to September, 2011 of the granular sludge.

In the pilot-scale SBR, small granules were observed after 7 days of operation. After operating for 50 days, aerobic granules with a mean diameter of $0.28 \mathrm{~mm}$ were dominant in the reactor. The MLSS and SVI of mature granular sludge were $7500 \mathrm{mg} \mathrm{L}^{-1}$ and $43 \mathrm{~mL} \mathrm{~g}^{-1}$, respectively. The average COD removal efficiency in two column reactors was stabled at $88 \%$ while $\mathrm{NH}_{4}{ }^{+}-\mathrm{N}$ was all removed. The result implied the feasibility of application of aerobic granular sludge in fullscale SBR in this plant.

Sludges from lab-scale SBR and pilot-scale SBR were photographed after operating for 43 days and 50 days, respectively (Figure 2 ). They showed similar dense structure, sharp and irregular outline.

3.2. Formation of Aerobic Granules in Full-Scale SBR and Comparison of Sludges from A/O, OD and Full-Scale SBR. After inoculation in the full-scale SBR, the SVI decreased from $75.5 \mathrm{~mL} \mathrm{~g}^{-1}$ of the inoculated sludge to $43 \mathrm{~mL} \mathrm{~g}^{-1}$ after 14 days operation. Then the SVI increased to $61 \mathrm{~mL} \mathrm{~g}^{-1}$ on day 21 and fell down to $43 \mathrm{~mL} \mathrm{~g}^{-1}$ on day 30 . In the next 310 days, the average SVI was stabled at $48 \mathrm{~mL} \mathrm{~g}^{-1}$ (Figure 3). Accordingly, the MLSS increased up to $6583 \mathrm{mg} \mathrm{L}^{-1}$ in day 38 with the decreasing of SVI. Then, the MLSS decreased gradually and stabilized at approximately $3600 \mathrm{~mL} \mathrm{~g}^{-1}$ due to discharging a certain amount of sludge every day including granules and some flocs (Figure 3).

The average SVI in the $\mathrm{A} / \mathrm{O}$ and $\mathrm{OD}$ process were $61.1 \mathrm{~mL} \mathrm{~g}^{-1}$ and $60.7 \mathrm{~mL} \mathrm{~g}^{-1}$ respectively (Table 2), which showed better settling ability compared with conventional activated sludge. The average MLSS concentrations and MLVSS to MLSS ratio in the A/O and OD process were $5471 \mathrm{mg} \mathrm{L}^{-1}, 5818 \mathrm{mg} \mathrm{L}^{-1}$ and $51.0 \%, 57.2 \%$, respectively. The sludge in the $\mathrm{A} / \mathrm{O}$ and $\mathrm{OD}$ process showed good settling ability due to relatively high inorganic proportions existing in activated sludge. The removal performance in $\mathrm{A} / \mathrm{O}$ and $\mathrm{OD}$ were kept well with $\mathrm{NH}_{4}{ }^{+}-\mathrm{N}$ removal rate of $94.3 \%$ and $94.8 \%$ 
TABLE 2: Comparison of sludges in A/O, OD, and full-scale SBRs.

\begin{tabular}{|c|c|c|c|}
\hline Process & Anaerobic/oxic & Oxidation ditch & Full-scale SBR \\
\hline Volumetric flow rate $\left(\mathrm{m}^{3} \mathrm{~d}^{-1}\right)$ & 10,000 & 50,000 & 50,000 \\
\hline Operating mode & Plug flow (A/O) & Continuous flow & Sequencing batch \\
\hline Substrate change & Feast-famine & Completely mixed & Feast-famine \\
\hline COD loading $\left(\mathrm{kg} \mathrm{m}^{3} \mathrm{~d}^{-1}\right)$ & 0.54 & 0.68 & 0.56 \\
\hline Ammonium loading $\left(\mathrm{kg} \mathrm{m}^{3} \mathrm{~d}^{-1}\right)$ & 0.025 & 0.031 & 0.022 \\
\hline Settling time $(\mathrm{min})$ & 150 & 150 & $70-80^{*}$ \\
\hline MLSS $\left(\mathrm{mg} \mathrm{L}^{-1}\right)$ & 5471 & 5818 & 3946 \\
\hline $\mathrm{SVI}_{30}\left(\mathrm{~mL} \mathrm{~g}^{-1}\right)$ & 61.1 & 60.7 & 47.1 \\
\hline MLVSS/MLSS & $56.3 \%$ & $57.2 \%$ & $62.4 \%$ \\
\hline Settling velocity $\left(\mathrm{m} \mathrm{h}^{-1}\right)$ & 10.4 & 9.2 & 42.0 \\
\hline $\begin{array}{l}\text { EPS (PS, mg/g VSS) } \\
\text { (PN, mg/g VSS) }\end{array}$ & $\begin{array}{c}13.0 \\
263.9\end{array}$ & $\begin{array}{c}15.2 \\
288.2\end{array}$ & $\begin{array}{c}20.8 \\
253.8\end{array}$ \\
\hline COD removal efficacy $(\%)$ & 82.2 & 81.3 & 85.0 \\
\hline $\mathrm{NH}_{4}{ }^{+}-\mathrm{N}$ removal efficacy (\%) & 94.3 & 94.8 & 95.8 \\
\hline TN removal efficacy (\%) & $25.3 \%$ & $22.7 \%$ & $59.6 \%$ \\
\hline
\end{tabular}

${ }^{*}$ Settling time in full-scale SBR includes 30 min of effluent withdraw.

*Samples from anaerobic/oxic reactor, oxidation ditch, and full scale sequencing batch reactor were taken at the same time on September 8, 2011.

TABLE 3: Similarity coefficients of microbial communities among the samples.

\begin{tabular}{lccc}
\hline Lane & 1 & 2 & 3 \\
\hline 1 & 1.00 & 0.72 & 0.37 \\
2 & 0.72 & 1.00 & 0.45 \\
3 & 0.37 & 0.45 & 1.00 \\
\hline
\end{tabular}

TABLE 4: Diversity index $(H)$ and number of the bands in DGGE profiles of sludge samples.

\begin{tabular}{lccc}
\hline Sample & 1 & 2 & 3 \\
\hline Number of bands & 23 & 24 & 21 \\
$H$ & 2.82 & 2.89 & 2.70 \\
\hline
\end{tabular}

and COD removal rate of $82.2 \%$ and $74.0 \%$, respectively. However, the TN removal rate in full-scale SBR was $59.6 \%$ which was much higher compared with $\mathrm{A} / \mathrm{O}$ and OD due to simultaneous nitrification and denitrification effect of aeobic granules. TP only decreased from $2.5 \mathrm{mg} / \mathrm{L}$ to $1.2 \mathrm{mg} / \mathrm{L}$ in fullscale SBR since there was no anaerobic phase existed and the removal of TP was mainly depend on post-treatment of physical and chemical. Granules in the full-scale SBR showed the best settling ability and the highest settling velocity among these three processes after granulation (Table 2). It indicates that aerobic granular sludge in the SBR process is advantageous compared to traditional activated sludge in the $\mathrm{A} / \mathrm{O}$ and OD process. A much higher settling velocity of aerobic granules allowed for less settling time in the SBR which in turn improved the wastewater treatment efficiency in the SBR. Furthermore, a short settling time favored the growth of rapidly-settling bioparticles whereas the bioparticles with a poor settling ability were washed out [12].
Through microscope and digital camera analysis, it could be found that small granules existed in activated sludge in both $\mathrm{A} / \mathrm{O}$ and $\mathrm{OD}$. The $\mathrm{A} / \mathrm{O}$ operated in a plug flow way while in the OD the wastewater was completely mixed. Hence, the substrate concentration in the $\mathrm{A} / \mathrm{O}$ experienced a change from high to low along the reactor length which matched the feast-famine regime while in the OD the substrate concentration had almost not changed. Furthermore, the secondary sedimentation tank with a long settling time (2.5 hours) could not offer enough selecting pressure to wash out the poorly settleable sludge. In addition, the aeration tank in the A/O and OD process was separated from the second sedimentation tank. Part of the settled sludge in the second sedimentation tank was pumped back to the aeration tank for recirculation. In this way, the granule was easily destroyed by the pump. In conclusion, it was tough to cultivate aerobic granules in the $\mathrm{A} / \mathrm{O}$ and $\mathrm{OD}$.

\subsection{DGGE Profile and Bacterial Community Analysis}

3.3.1. DGGE Profile and Phylogenetic Analysis. DGGE profiles (Figure 4) and similarity coefficient analysis (Table 3 ) indicated that under continuous flow (A/O and OD) and SBR conditions, the bacterial community composition especially for bacterial species showed a remarkable difference. Most of the bacterial species in activated sludge in A/O and OD were similar, but a noticeable difference occurred in mature aerobic granules in the full-scale SBR. It had been previously reported that the influence of operation conditions and reactor format on the community diversity was evidenced by the change in band patterns [29].

Schematic band intensities for DGGE profiles were obtained using BanScan software (Figure 4(b)). There were 32 obvious bands in DGGE profiles with 21-24 bands in every sample (Figure 4), and there was no obvious difference 


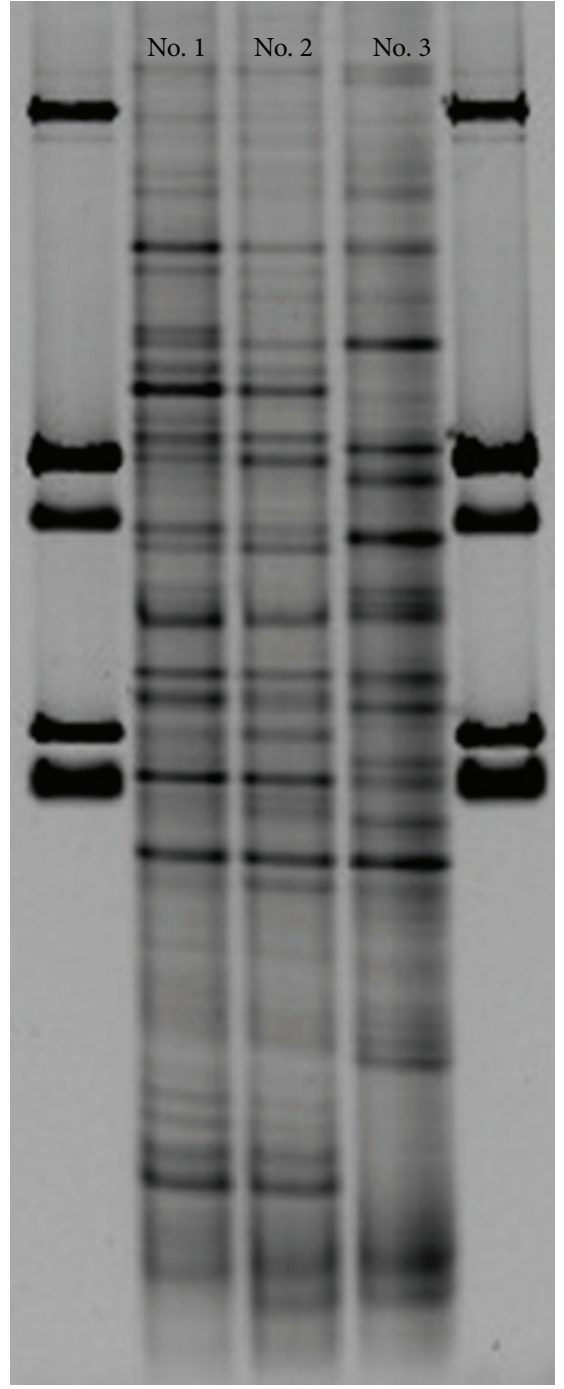

(a) DGGE profiles of examined samples

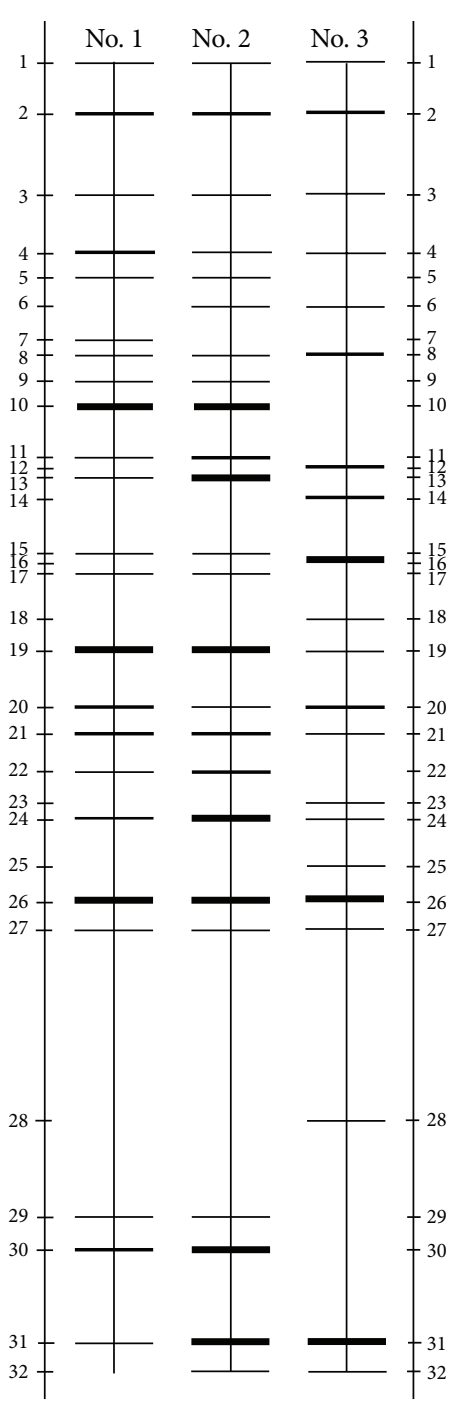

(b) Schematic diagram of relative band intensities in DGGE

FIGURE 4: The DGGE profiles of bacterial communities in three different reactors and all sludge samples were collected on September 8, 2011. 1\#: sludge from A/O; 2\#: sludge from OD; 3\#: sludge from full-scale SBR.

in the number of bands and the diversity index among the samples (Table 4). As measured, similarity coefficients of $1 \#$ and 2\# were relatively high (Table 3 ). Some bands, such as bands $1,2,3,4,8,19,20,21,24,26,27$ and 31 were found in all of the samples under three different processes. However, the relative intensities of the same band in different sample profiles were different. Besides, some special bands appeared in the DGGE profiles of different samples such as band 14, 16, 18 and 20, which only existed in 3\# (Figure 4(b)).

Typical bands from the DGGE profiles were separated, reamplified, sequenced and thirteen sequences were obtained. Nucleotide sequences and the abundance of sequenced DGGE bands were compared (Table 5). Sequence analysis showed that bands 10, 12, 16 and 26 had similarity levels of $100 \%, 99 \%, 100 \%$ and $100 \%$, respectively, which was more than the genus similarity level [30]. It was therefore considered that sequences of these four bands were from Nitrospira, Flavobacterium, Aquabacterium and Thauera genus, respectively. According to the DGGE profiles, Flavobacterium (band 12) dominated in the granules from the full-scale SBR although it was not the dominant group in the initial sludge from the OD used as seed sludge. It was reported that Flavobacterium is a significant genera of floc-forming bacteria [31] producing extracellular polymers to bind cells together. Earlier works also proved that Flavobacterium was dominant in granules from the full-scale SBR while not dominant in seed sludge [32]. It was interesting to note that Bacteroidetes (band 13) was dominant in $\mathrm{A} / \mathrm{O}$ and $\mathrm{OD}$ but did not exist in the granular sludge in the full-scale SBR. Former works had proved that the Bacteroidetes bacterium 
TABLE 5: Comparison of nucleotide sequences and abundance of sequenced DGGE bands.

\begin{tabular}{|c|c|c|c|c|c|c|c|}
\hline \multirow{2}{*}{ Band } & \multirow{2}{*}{$\begin{array}{l}\text { Sequence } \\
\text { (bp) }\end{array}$} & \multirow{2}{*}{$\begin{array}{l}\text { Accession } \\
\text { no. }\end{array}$} & \multirow{2}{*}{ Closest relative (accession no.) } & \multirow{2}{*}{$\begin{array}{c}\text { Identity } \\
(\%)\end{array}$} & \multicolumn{3}{|c|}{ Relative abundance of bands (\%) } \\
\hline & & & & & $1 \#$ & $2 \#$ & 3\# \\
\hline 4 & 188 & KF234427 & Uncultured bacterium clone ASNR-16 (JQ809244) & 100 & 7.0 & 2.3 & 4.2 \\
\hline 8 & 188 & KF234428 & $\begin{array}{l}\text { Uncultured Chlorobi bacterium clone ABL17 } \\
\text { (JQ906960) }\end{array}$ & 97 & 1.3 & 1.9 & 8.4 \\
\hline 10 & 183 & KF234429 & Uncultured Nitrospira sp. (KC491391) & 100 & 11.5 & 6.7 & ND \\
\hline 11 & 193 & KF234430 & $\begin{array}{l}\text { Uncultured Nitrosomonas sp. clone S12 } \\
\text { (AY605680) }\end{array}$ & 99 & 3.5 & 3.7 & ND \\
\hline 12 & 187 & KF234431 & Flavobacterium sp. R046 (KC252875) & 99 & ND & ND & 7.1 \\
\hline 13 & 188 & KF273869 & Uncultured Bacteroidetes bacterium (FJ750465) & 100 & 1.4 & 6.8 & ND \\
\hline 14 & 193 & KF234435 & Uncultured beta proteobacterium (AB636023) & 100 & ND & ND & 5.7 \\
\hline 16 & 193 & KF234436 & Uncultured Aquabacterium sp. (JQ288705) & 99 & ND & ND & 12.8 \\
\hline 18 & 193 & KF234437 & Leptothrix sp. (JQ946011) & 100 & ND & ND & 5.7 \\
\hline 23 & 170 & KF234438 & $\begin{array}{l}\text { Uncultured Alphaproteobacteriabacterium } \\
\text { (CU925173) }\end{array}$ & 100 & ND & ND & 1.5 \\
\hline 25 & 193 & KF234441 & Uncultured bacterium (KC541099) & 98 & ND & ND & 3.6 \\
\hline 26 & 193 & KF234444 & $\begin{array}{l}\text { Thauera sp. enrichment culture clone LDC-8 } \\
\text { (KF020718) }\end{array}$ & 100 & 8.4 & 9.2 & 10.6 \\
\hline 28 & 196 & KF234446 & Uncultured proteobacterium (GQ243004) & 98 & ND & ND & 2.6 \\
\hline
\end{tabular}

ND: not detected.

The bands are designed as shown in Figure 4.

The abundance was calculated using BandScan (version 5.0) software.

was washed out at short settling times and did not contribute to sludge granulation [33]. In our study, the Bacteroidetes bacterium was washed out under SBR operational conditions, but retained under $\mathrm{A} / \mathrm{O}$ and $\mathrm{OD}$ operational conditions due to the longer settling time. Nitrospira (band 10) dominated in $\mathrm{A} / \mathrm{O}$ and $\mathrm{OD}$ but not in the full-scale SBR after granulation. Thauera (band 26) was present significantly in all three reactors and it played an important role in nitrogen removal [33].

\subsection{Main Factors for Aerobic Granulation in Full-Scale SBR}

3.4.1. The Effect of Raw Wastewater on Aerobic Granulation. Excellent performance of aerobic granules in the lab-scale SBR, pilot-scale SBR, and particularly full-scale SBR suggested a necessary discussion about the role of raw wastewater in aerobic granulation.

Chemical elements in raw wastewater and granules from the full scale SBR were analyzed by XRF (Figure 5). The contents of $\mathrm{Na}$ and $\mathrm{Cl}$ were $35.43 \%$ and $17.59 \%$ respectively in raw wastewater due to the fact that this WWTP is located at the seaside and is treating some industrial wastewater. It was reported that the presence of salt in the treated effluent did not cause a detrimental effect on the operation of the reactor once the aerobic granules were formed [34] or the granular structure was stable throughout the whole experimental period when subjected to different salinity [35]. It indicated that $\mathrm{Fe}, \mathrm{Si}, \mathrm{Ca}$ and $\mathrm{P}$ were precipitated in aerobic granules since the contents of these elements in granules were higher than those in raw wastewater. It had been demonstrated that the presence of divalent and trivalent mental ions could act as a bridge between negatively charged groups on the cell surface which was important in the aggregation progress $[36,37]$. The effect of $\mathrm{Ca}^{2+}$ and $\mathrm{Mg}^{2+}$ enhancing the sludge granulation in the SBR was widely recognized [38-40]. Some studies indicated that $\mathrm{Al}$ and Fe were necessary in the development of compact aerobic granules structure with excellent settling properties $[41,42]$. Si was also precipitated significantly in granules; it had been reported that Si laid the foundations for the aerobic granule structure and supported the strength of matured granules [41].

Large amounts of inorganics composed of $\mathrm{Fe}, \mathrm{Si}, \mathrm{Ca}$ and $\mathrm{P}$ existing in the raw wastewater obviously provided nuclei to accelerate microbial aggregation. These inorganic solids were found in aerobic granules from this full-scale SBR (Figure 6). Huishoff used hydro-anthracite as an additional inert support particle accelerating the anaerobic granulation [43]. Granular activated carbon (GAC) was also added for sludge granulation in the SBR with low-strength wastewater [44]. Powdered activated carbon (PAC) and GAC were added during the start-up of upflow anaerobic sludge blanket (UASB) to accelerate granulation [45]. However, these inorganics also caused low VSS/SS ratio in sludge.

It was believed that the formation and stability of aerobic granules were closely related to the sludge EPS [46]. Therefore, the EPS content of sludge in A/O, OD and full-scale SBR were analyzed respectively (Table 2). The presence of high PN contents in these three different sludges indicated the probable effect of raw wastewater in WWTP, which contained bio-refractory or toxic compounds such as Benzenamine, Benzenamine N-methyl- and Isoquinoline (Figure 7). Previous studies implied that the EPS production, especially 

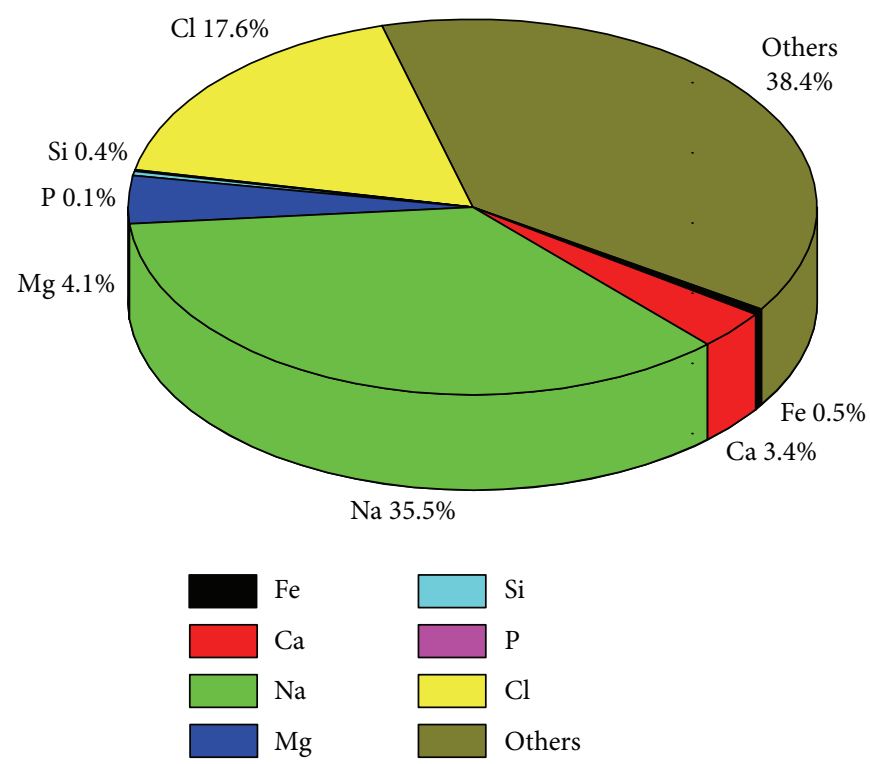

(a) Raw wastewater

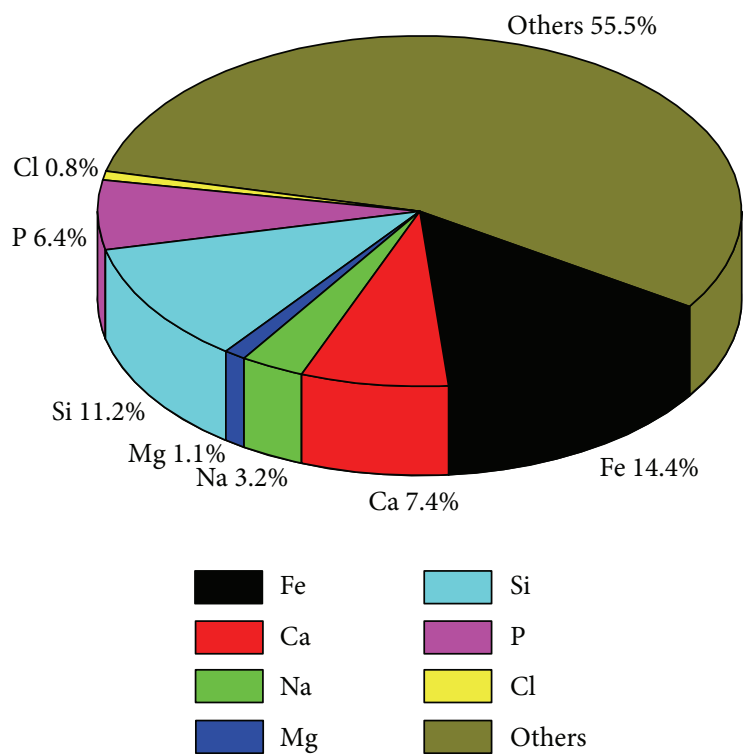

(b) Granular sludge in full-scale SBR

FIGURE 5: Element analysis of raw wastewater and granular sludge in full-scale SBR by X-ray fluorescence (XRF).

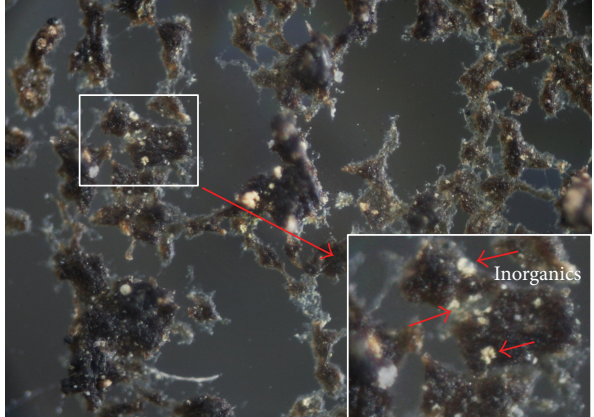

FIGURE 6: Image of dry aerobic granular sludge from full-scale SBR. Some inorganics act as cores in granules showed by short arrows.

the protein components of microbes, increased due to the exposure to toxic environment [47]. The PS content in the full-scale SBR of $20.8 \mathrm{mg} \mathrm{g}^{-1}$ VSS was higher than in the $\mathrm{A} / \mathrm{O}\left(15.2 \mathrm{mg} \mathrm{g}^{-1}\right.$ VSS and OD of $13.0 \mathrm{mg} \mathrm{g}^{-1}$ VSS). PS could mediate both cohesion and adhesion of cells, and played an important role in maintaining the structure and stability of aerobic granules [48].

\subsubsection{The Effect of Operating Mode on Aerobic Granulation.} Comparing the operating mode of SBR with $\mathrm{A} / \mathrm{O}$ and OD, the unique feature of the full-scale SBR was its cyclic operation mode which would lead to a periodical biodegradation phase followed by an aerobic starvation phase in every cycle. Ammonia nitrogen, nitrite, nitrate, total nitrogen and $\mathrm{BOD}_{5}$ undergo degradation during a typical cycle of operation (Figure 8). After aeration for $2 \mathrm{~h}, \mathrm{BOD}_{5}$ was decreased to the lowest of $15 \mathrm{mg} \mathrm{L}^{-1}$. The rest of the aeration time of about $3 \mathrm{~h}$ for nitrification caused a starvation period of bacteria.
Thus, it was likely that microorganism in the SBR were subject to a periodic starvation. After aeration for about 3 hours, due to the degradation of contaminants the aeration intensity decreased for energy saving reasons. The periodic feastfamine conditions facilitated microbial aggregation. Due to the increasing hydrophobicity of the bacteria, a decrease of surface negative charge could be observed [49]. It could be a reason that the most reactors for cultivating aerobic granular sludge were SBR.

The A/O process operated in a plug flow way meaning that an existing feast-famine regime contributed to microbial aggregates. Nevertheless, granules were not formed in the $\mathrm{A} / \mathrm{O}$ process due to long settling time. Aerobic granules could not be successfully developed if the settling time was not well controlled, even though a periodic feast-famine regime was present $[50,51]$. In the SBR, settling time and volume exchange ratio could be easily controlled which acted as the main hydraulic selecting pressures inducing aerobic granulation [52]. Moreover, the mixed liquor flowed into the secondary sedimentation tank for settling in continuous flow process. Part of the settled sludge was returned back to the aeration tank by pumping which could easily destroy the aggregated sludge. Consequently, it was also one reason for an incomplete granulation in the $\mathrm{A} / \mathrm{O}$ or $\mathrm{OD}$.

\section{Conclusion}

Aerobic granular sludge was successfully cultivated in a lab-scale and a pilot-scale SBR in a WWTP. Subsequently, mature granules with compact structure, an average $\mathrm{SVI}_{30}$ of $47.1 \mathrm{~mL} \mathrm{~g}^{-1}$, a diameter of $0.5 \mathrm{~mm}$ and a settling velocity of $48 \mathrm{~m} \mathrm{~h}^{-1}$ were achieved in a full-scale SBR. Compared to two continuous flow reactors $(\mathrm{A} / \mathrm{O}$ and $\mathrm{OD})$ in this plant, different microbial communities were found in the full-scale 


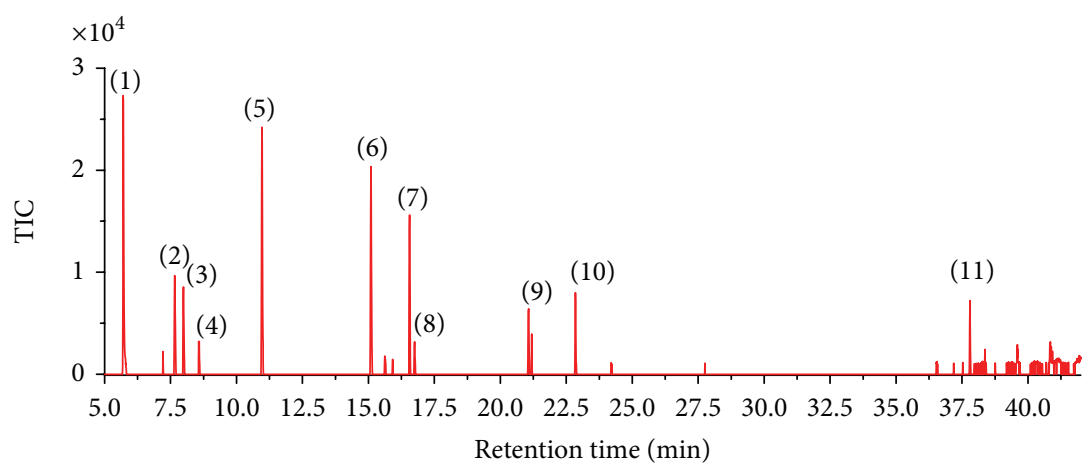

Figure 7: Volatile and semi-volatile organic compounds in raw wastewater by GC/MS analysis: (1) 2-Bromo-2-nitropropane (2) Propanoic acid, 2-hydroxy-, 2-methylpropyl ester (3) Formic acid, 2-propenyl ester (4) Aniline (5) Anline, N-methyl- (6) Isoquinoline (7) 4Aminoheptane (8) 1,2,4-Thiadiazole, 5-amino-3-propyl- (9) Phenol, 3,5-bis(1,1-dimethylethyl)- (10) Pyrimidine-2,4(1H,3H)-dione, 5-amino6-nitroso (11) Oxalic acid, isobutyl propyl ester.

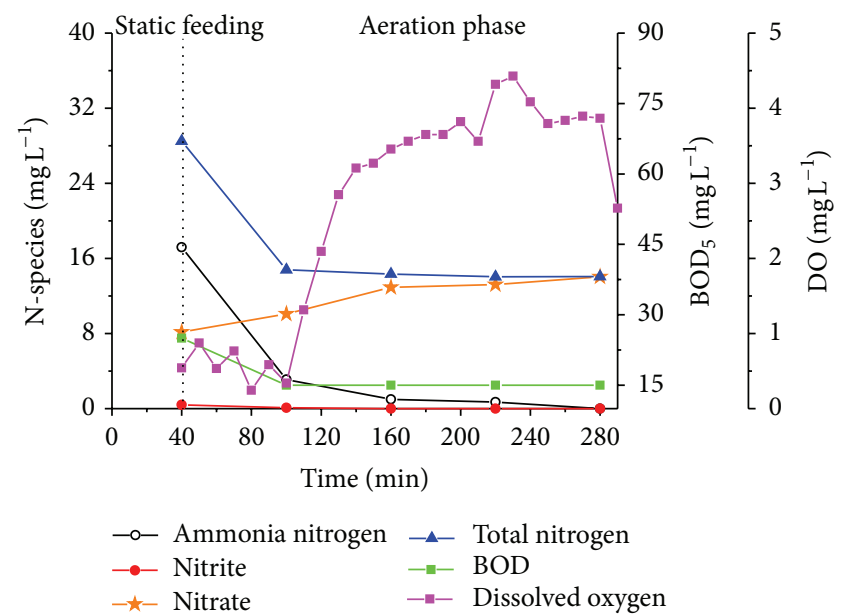

FIgUre 8: Profiles of $\mathrm{NH}_{4}{ }^{+}-\mathrm{N}, \mathrm{NO}_{2}{ }^{-}-\mathrm{N}, \mathrm{NO}_{3}{ }^{-}-\mathrm{N}, \mathrm{TN}, \mathrm{DO}$ and BOD concentrations with in a representative cycle in full-scale SBR. Note the influent with $\mathrm{NH}_{4}{ }^{+}-\mathrm{N}$ of $28.2 \mathrm{mg} \mathrm{L}^{-1}$, TN of $34.5 \mathrm{mg} \mathrm{L}^{-1}, \mathrm{BOD}_{5}$ of $85 \mathrm{mg} \mathrm{L}^{-1}$.

SBR. The reasons for aerobic granulation in the SBR were related to the composition of raw wastewater and operating mode such as periodic feast-famine, shorter settling time and no return sludge pump.

\section{Highlights}

Aerobic granulation was achieved in a $50,000 \mathrm{~m}^{3} \mathrm{~d}^{-1}$ SBR treating a town's wastewater.

Granular sludge from SBR has more compact structure and excellent settling ability.

Bacterial species were distinct in sludges from continuous flow and SBR in this WWTP.

Raw wastewater composition and SBR operating mode were key factors for granulation.

\section{Conflict of Interests}

The authors declare that there is no conflict of interests.

\section{Acknowledgments}

This research was supported by the National Natural Science Foundation of China (No. 50878195) and the Project of Science and Technology of Zhejiang.

\section{References}

[1] Y.-Q. Liu, Y. Kong, J.-H. Tay, and J. Zhu, "Enhancement of start-up of pilot-scale granular SBR fed with real wastewater," Separation and Purification Technology, vol. 82, no. 1, pp. 190196, 2011.

[2] M. Verawaty, M. Pijuan, Z. Yuan, and P. L. Bond, "Determining the mechanisms for aerobic granulation from mixed seed of floccular and crushed granules in activated sludge wastewater treatment," Water Research, vol. 46, no. 3, pp. 761-771, 2012.

[3] K. Z. Su, B. J. Ni, and H. Q. Yu, "Modeling and optimization of granulation process of activated sludge in sequencing batch reactors," Biotechnology and Bioengineering, vol. 110, no. 5, pp. 1312-1322, 2013.

[4] Y. Liu and J.-H. Tay, "State of the art of biogranulation technology for wastewater treatment," Biotechnology Advances, vol. 22, no. 7, pp. 533-563, 2004.

[5] S. S. Adav, D.-J. Lee, K.-Y. Show, and J.-H. Tay, "Aerobic granular sludge: recent advances," Biotechnology Advances, vol. 26, no. 5, pp. 411-423, 2008.

[6] X.-W. Liu, G.-P. Sheng, and H.-Q. Yu, "Physicochemical characteristics of microbial granules," Biotechnology Advances, vol. 27, no. 6, pp. 1061-1070, 2009.

[7] M. K. Jungles, M. Figueroa, N. Morales et al., "Start up of a pilot scale aerobic granular reactor for organic matter and nitrogen removal," Journal of Chemical Technology and Biotechnology, vol. 86, no. 5, pp. 763-768, 2011.

[8] Y. Liu, Z.-W. Wang, and J.-H. Tay, "A unified theory for upscaling aerobic granular sludge sequencing batch reactors," Biotechnology Advances, vol. 23, no. 5, pp. 335-344, 2005. 
[9] D.-J. Lee, Y.-Y. Chen, K.-Y. Show, C. G. Whiteley, and J.-H. Tay, "Advances in aerobic granule formation and granule stability in the course of storage and reactor operation," Biotechnology Advances, vol. 28, no. 6, pp. 919-934, 2010.

[10] B.-J. Ni and H.-Q. Yu, "Mathematical modeling of aerobic granular sludge: a review," Biotechnology Advances, vol. 28, no. 6, pp. 895-909, 2010.

[11] M. K. de Kreuk, Aerobic granular sludge: scaling up a new technology [Ph.D. thesis], Delft University of Technology, Delft, The Netherlands, 2006.

[12] B.-J. Ni, W.-M. Xie, S.-G. Liu et al., "Granulation of activated sludge in a pilot-scale sequencing batch reactor for the treatment of low-strength municipal wastewater," Water Research, vol. 43, no. 3, pp. 751-761, 2009.

[13] L. M. M. de Bruin, H. F. van der Roest, and M. C. M. van Loosdrecht, "Overview of applied research with nereda-technology in the Netherlands," Proceedings of the Water Environment Federation, vol. 2010, no. 7, pp. 103-113, 2010.

[14] E. Isanta, M. E. Suárez-Ojeda, Á. Val del Río, N. Morales, J. Pérez, and J. Carrera, "Long term operation of a granular sequencing batch reactor at pilot scale treating a low-strength wastewater," Chemical Engineering Journal, vol. 198-199, pp. 163$170,2012$.

[15] A. Giesen, L. de Bruin, R. Niermans, and H. van der Roest, "Advancements in the application of aerobic granular biomass technology for sustainable treatment of wastewater," Water Practice and Technology, vol. 8, no. 1, pp. 47-54, 2013.

[16] P. Inocencio, F. Coelho, M. van Loosdrecht, and A. Giesen, “The future of sewage treatment: nereda technology exceeds high expectations," Water, vol. 21, pp. 28-29, 2013.

[17] T. Rocktäschel, C. Klarmann, B. Helmreich et al., "Comparison of two different anaerobic feeding strategies to establish a stable aerobic granulated sludge bed," Water Research, vol. 47, no. 17, pp. 6423-6431, 2013.

[18] G. E. Gademan, P. N. Gaydon, and B. de Bruin, "Granular aerobic activated sludge," http:// www.ewisa.co.za/literature/ files/394_286 Gademan.pdf.

[19] Y. Kong, Y.-Q. Liu, J.-H. Tay, F.-S. Wong, and J. Zhu, "Aerobic granulation in sequencing batch reactors with different reactor height/diameter ratios," Enzyme and Microbial Technology, vol. 45, no. 5, pp. 379-383, 2009.

[20] APHA, Standard Methods for the Examination of Water and Wastewater, American Public Health Association, Washington, DC, USA, 19th edition, 1995.

[21] X. Zhang, P. L. Bishop, and B. K. Kinkle, "Comparison of extraction methods for quantifying extracellular polymers in biofilms," Water Science and Technology, vol. 39, no. 7, pp. 211218, 1999.

[22] M. Lever, "A new reaction for colorimetric determination of carbohydrates," Analytical Biochemistry, vol. 47, no. 1, pp. 273279, 1972.

[23] O. H. Lowry, N. J. Rosebrough, A. L. Farr, and R. J. Randall, "Protein measurement with the Folin phenol reagent," The Journal of Biological Chemistry, vol. 193, no. 1, pp. 265-275, 1951.

[24] G. Muyzer, E. C. de Waal, and A. G. Uitterlinden, "Profiling of complex microbial populations by denaturing gradient gel electrophoresis analysis of polymerase chain reaction-amplified genes coding for 16S rRNA," Applied and Environmental Microbiology, vol. 59, no. 3, pp. 695-700, 1993.

[25] S. T.-L. Tay, V. Ivanov, S. Yi, W.-Q. Zhuang, and J.-H. Tay, "Presence of anaerobic bacteroides in aerobically grown microbial granules," Microbial Ecology, vol. 44, no. 3, pp. 278-285, 2002.
[26] Y.-Q. Liu, J.-H. Tay, and B. Y.-P. Moy, “Characteristics of aerobic granular sludge in a sequencing batch reactor with variable aeration," Applied Microbiology and Biotechnology, vol. 71, no. 5, pp. 761-766, 2006.

[27] V. Andreoni, L. Cavalca, M. A. Rao et al., "Bacterial communities and enzyme activities of PAHs polluted soils," Chemosphere, vol. 57, no. 5, pp. 401-412, 2004.

[28] B. V. Kjellerup, R. H. Veeh, P. Sumithraratne et al., "Monitoring of microbial souring in chemically treated, producedwater biofilm systems using molecular techniques," Journal of Industrial Microbiology and Biotechnology, vol. 32, no. 4, pp. 163-170, 2005.

[29] M. K. Pholchan, J. D. C. Baptista, R. J. Davenport, and T. P. Curtis, "Systematic study of the effect of operating variables on reactor performance and microbial diversity in laboratory-scale activated sludge reactors," Water Research, vol. 44, no. 5, pp. 1341-1352, 2010.

[30] E. González-Toril, E. Llobet-Brossa, E. O. Casamayor, R. Amann, and R. Amils, "Microbial ecology of an extreme acidic environment, the Tinto River," Applied and Environmental Microbiology, vol. 69, no. 8, pp. 4853-4865, 2003.

[31] M. H. Gerardi, Wastewater Bacteria, vol. 5, John Wiley \& Sons, Hoboken, NJ, USA, 2006.

[32] A.-J. Li, S.-F. Yang, X.-Y. Li, and J.-D. Gu, "Microbial population dynamics during aerobic sludge granulation at different organic loading rates," Water Research, vol. 42, no. 13, pp. 3552-3560, 2008.

[33] B. Zhang, M. Ji, Z. Qiu, H. Liu, J. Wang, and J. Li, "Microbial population dynamics during sludge granulation in an anaerobic-aerobic biological phosphorus removal system," Bioresource Technology, vol. 102, no. 3, pp. 2474-2480, 2011.

[34] M. Figueroa, A. Mosquera-Corral, J. L. Campos, and R. Méndez, "Treatment of saline wastewater in SBR aerobic granular reactors," Water Science and Technology, vol. 58, no. 2, pp. 479-485, 2008.

[35] M. Pronk, J. P. Bassin, M. K. de Kreuk, R. Kleerebezem, and M. C. M. van Loosdrecht, "Evaluating the main and side effects of high salinity on aerobic granular sludge," Applied Microbiology and Biotechnology, vol. 98, no. 3, pp. 1339-1348, 2014.

[36] E. M. Mahoney, L. K. Varangu, W. L. Cairns, N. Kosaric, and R. G. E. Murray, "The effect of calcium on microbial aggregation during uasb reactor start-up," Water Science and Technology, vol. 19, no. 1-2, pp. 249-260, 1987.

[37] N. Kosaric and R. Blaszczyk, "Microbial aggregates in anaerobic wastewater treatment," Advances in Biochemical Engineering/Biotechnology, vol. 42, pp. 27-62, 1990.

[38] H.-L. Jiang, J.-H. Tay, Y. Liu, and S. T.-L. Tay, " $\mathrm{Ca}^{2+}$ augmentation for enhancement of aerobically grown microbial granules in sludge blanket reactors," Biotechnology Letters, vol. 25, no. 2, pp. 95-99, 2003.

[39] X.-M. Li, Q.-Q. Liu, Q. Yang et al., "Enhanced aerobic sludge granulation in sequencing batch reactor by $\mathrm{Mg}^{2+}$ augmentation," Bioresource Technology, vol. 100, no. 1, pp. 64-67, 2009.

[40] T.-T. Ren, L. Liu, G.-P. Sheng et al., "Calcium spatial distribution in aerobic granules and its effects on granule structure, strength and bioactivity," Water Research, vol. 42, no. 13, pp. 3343-3352, 2008.

[41] I. Othman, A. N. Anuar, Z. Ujang, N. H. Rosman, H. Harun, and S. Chelliapan, "Livestock wastewater treatment using aerobic granular sludge," Bioresource Technology, vol. 133, pp. 630-634, 2013. 
[42] V. Agridiotis, C. F. Forster, and C. Carliell-Marquet, "Addition of $\mathrm{Al}$ and Fe salts during treatment of paper mill effluents to improve activated sludge settlement characteristics," Bioresource Technology, vol. 98, no. 15, pp. 2926-2934, 2007.

[43] L. Hulshoff Pol, The phenomenon of granulation of anaerobic sludge [Doctoral dissertation], Landbouwuniversiteit te Wageningen, 1989.

[44] A.-J. Li, X.-Y. Li, and H.-Q. Yu, "Granular activated carbon for aerobic sludge granulation in a bioreactor with a low-strength wastewater influent," Separation and Purification Technology, vol. 80, no. 2, pp. 276-283, 2011.

[45] H. Q. Yu, J. H. Tay, and H. H. P. Fang, "Effects of added powdered and granular activated carbons on start-up performance of UASB reactors," Environmental Technology, vol. 20, no. 10, pp. 1095-1101, 1999.

[46] T. Seviour, M. Pijuan, T. Nicholson, J. Keller, and Z. Yuan, "Gelforming exopolysaccharides explain basic differences between structures of aerobic sludge granules and floccular sludges," Water Research, vol. 43, no. 18, pp. 4469-4478, 2009.

[47] G.-P. Sheng, H.-Q. Yu, and Z.-B. Yue, "Production of extracellular polymeric substances from Rhodopseudomonas acidophila in the presence of toxic substances," Applied Microbiology and Biotechnology, vol. 69, no. 2, pp. 216-222, 2005.

[48] J.-H. Tay, Q.-S. Liu, and Y. Liu, "The role of cellular polysaccharides in the formation and stability of aerobic granules," Letters in Applied Microbiology, vol. 33, no. 3, pp. 222-226, 2001.

[49] Z. H. Li, T. Kuba, and T. Kusuda, "The influence of starvation phase on the properties and the development of aerobic granules," Enzyme and Microbial Technology, vol. 38, no. 5, pp. 670674, 2006.

[50] L. Qin, Y. Liu, and J.-H. Tay, "Effect of settling time on aerobic granulation in sequencing batch reactor," Biochemical Engineering Journal, vol. 21, no. 1, pp. 47-52, 2004.

[51] L. Qin, J.-H. Tay, and Y. Liu, "Selection pressure is a driving force of aerobic granulation in sequencing batch reactors," Process Biochemistry, vol. 39, no. 5, pp. 579-584, 2004.

[52] Y. Liu, Z.-W. Wang, L. Qin, Y.-Q. Liu, and J.-H. Tay, "Selection pressure-driven aerobic granulation in a sequencing batch reactor," Applied Microbiology and Biotechnology, vol. 67, no. 1, pp. 26-32, 2005. 

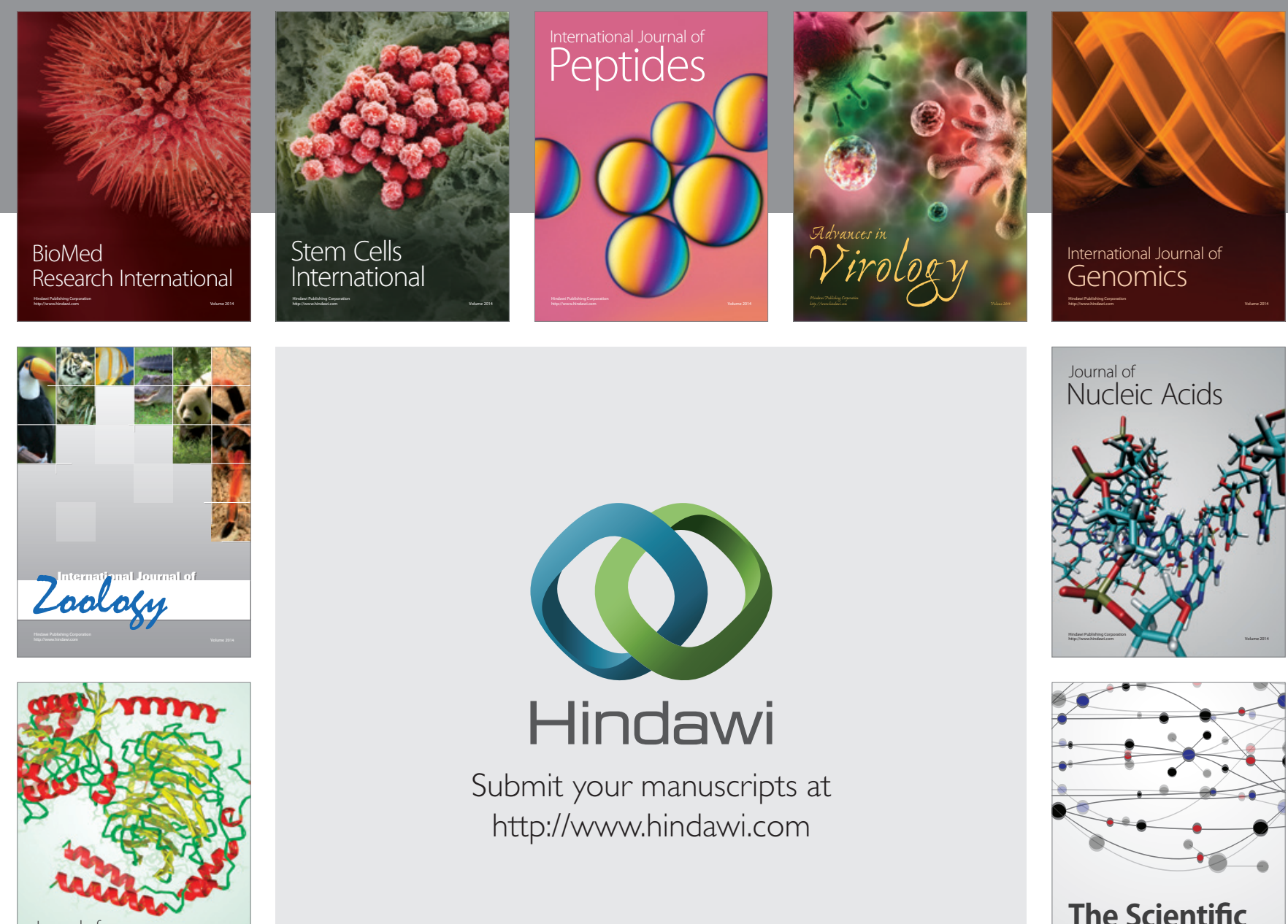

Submit your manuscripts at

http://www.hindawi.com

Journal of
Signal Transduction
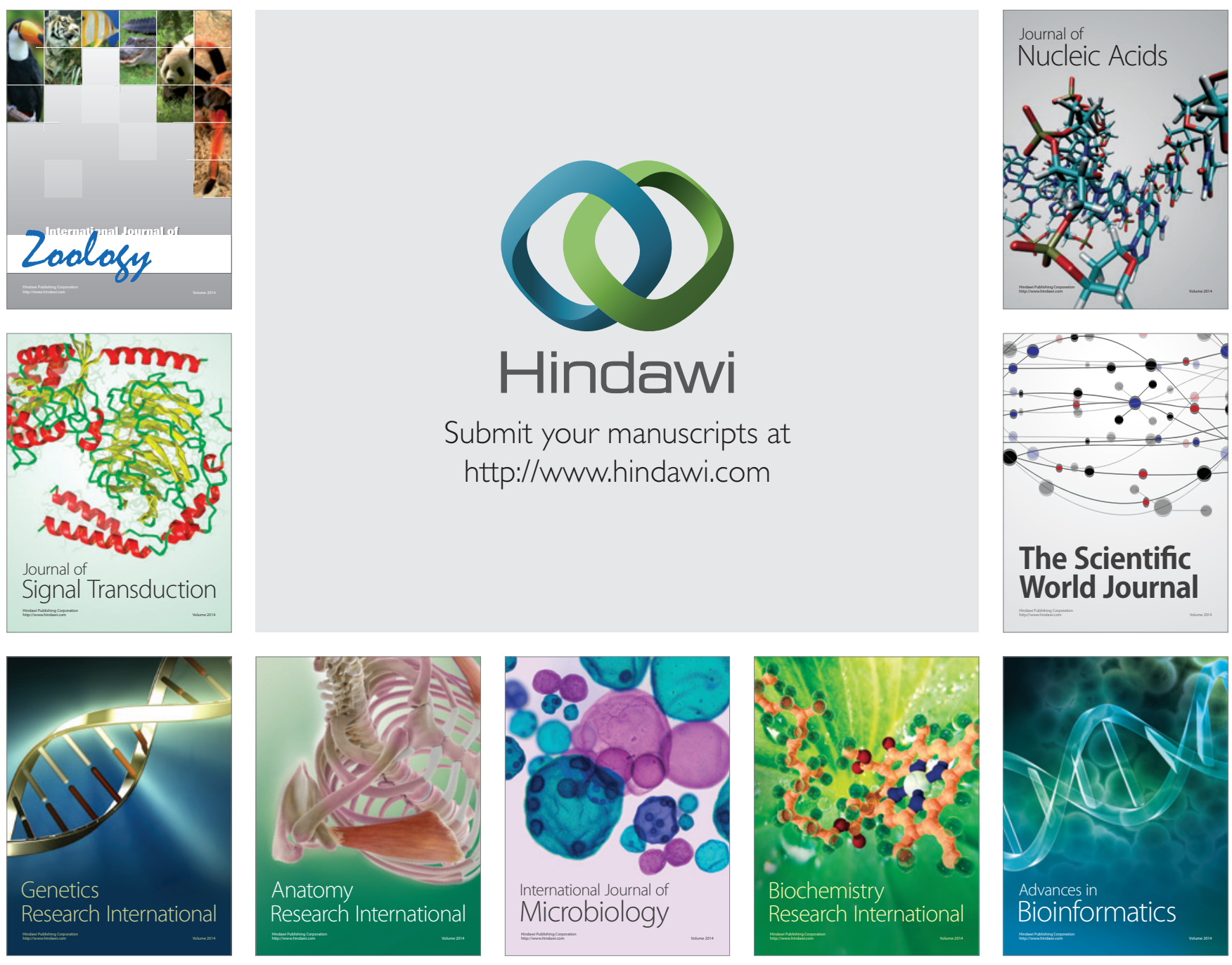

The Scientific World Journal
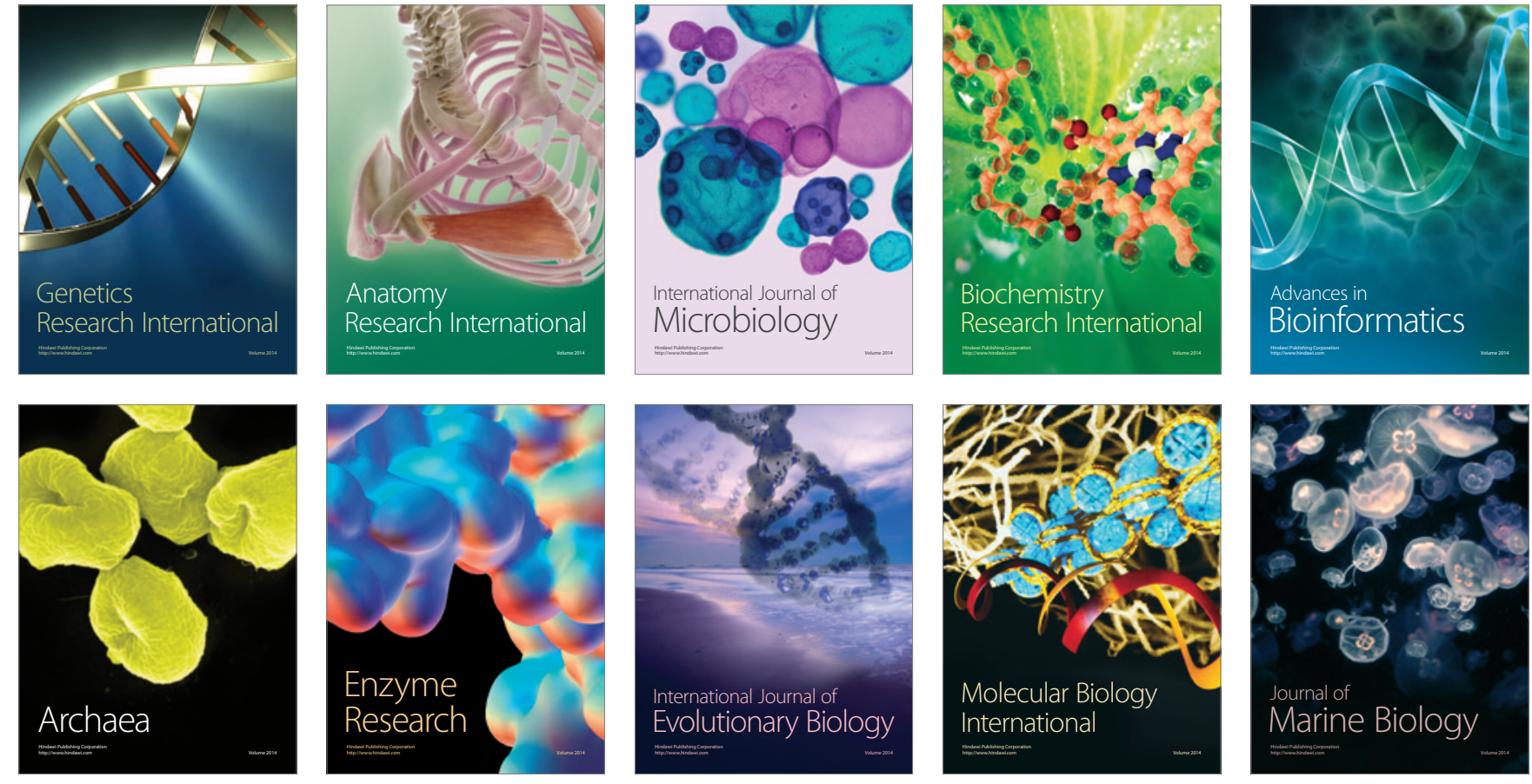